\title{
Engineered telomere degradation models dyskeratosis congenita
}

\author{
Dirk Hockemeyer, ${ }^{1,4}$ Wilhelm Palm, ${ }^{1,5}$ Richard C. Wang, ${ }^{2}$ Suzana S. Couto, ${ }^{3}$ and Titia de Lange ${ }^{1,6}$ \\ ${ }^{1}$ Laboratory for Cell Biology and Genetics, The Rockefeller University, New York, New York 10065, USA; ${ }^{2}$ Department of \\ Dermatology, University of Texas Southwestern Medical Center at Dallas, Dallas, Texas 75390, USA; ${ }^{3}$ Pathology and \\ Laboratory Medicine, Memorial Sloan-Kettering Cancer Center, New York, New York 10065, USA
}

\begin{abstract}
Dyskeratosis congenita (DC) is an inherited bone marrow failure syndrome characterized by cutaneous symptoms, including hyperpigmentation and nail dystrophy. Some forms of DC are caused by mutations in telomerase, the enzyme that counteracts telomere shortening, suggesting a telomere-based disease mechanism. However, mice with extensively shortened telomeres due to telomerase deficiency do not develop the characteristics of DC, raising questions about the etiology of DC and/or mouse models for human telomere dysfunction. Here we describe mice engineered to undergo telomere degradation due to the absence of the shelterin component POT1b. When combined with reduced telomerase activity, POT1b deficiency elicits several characteristics of DC, including hyperpigmentation and fatal bone marrow failure at 4-5 mo of age. These results provide experimental support for the notion that DC is caused by telomere dysfunction, and demonstrate that key aspects of a human telomere-based disease can be modeled in the mouse.
\end{abstract}

[Keywords: Bone marrow failure; dyskeratosis congenita; POT1; shelterin; telomere; telomerase]

Supplemental material is available at http://www.genesdev.org.

Received March 28, 2008; revised version accepted April 29, 2008.

DC is a rare hereditary multisystem disorder (for review, see Dokal and Vulliamy 2005). In addition to fatal bone marrow failure in the first or second decade, the characteristic symptoms of DC are nail dystrophy, reticulated hyperpigmentation of the skin, and leukoplakia of the buccal mucosa. DC patients can present with various other features including testicular atrophy, pulmonary fibrosis, liver cirrhosis, predisposition to cancer, osteoporosis, abnormal dentition, and mental retardation. DC has been proposed recently to be part of a spectrum of related syndromes with diverse clinical manifestations (Yaghmai et al. 2000; Yamaguchi et al. 2003; Yamaguchi et al. 2005; Armanios et al. 2007). DC-like syndromes may therefore be more frequent than previously inferred.

Autosomal forms of DC can be caused by mutations in the genes encoding the RNA (hTR) or reverse transcriptase (hTERT) components of telomerase (Vulliamy et al. 2001; Armanios et al. 2005; Marrone et al. 2007). In mammals, telomerase is required to counteract the attrition of telomeric DNA, which has been argued to result primarily from nucleolytic processing of the C-rich telomeric DNA strand (Lingner et al. 1995; Makarov et

Present addresses: ${ }^{4}$ Whitehead Institute for Biomedical Research, 9 Cambridge Center, Boston, MA 02142, USA; ${ }^{5}$ Max Planck Institute of Molecular Cell Biology and Genetics, Pfotenhauerstrasse 108, 01307 Dresden, Germany.

${ }^{6}$ Corresponding author.

E-MAIL delange@mail.rockefeller.edu; FAX (212) 327-7147.

Article published online ahead of print. Article and publication date are online at http://www.genesdev.org/cgi/doi/10.1101/gad.1679208. al. 1997). Whereas telomerase is absent from most human somatic cells, its activity is detectable in certain stem cell compartments, including the bone marrow. Telomerase is inferred to extend the replicative life span of hematopoietic stem cells (Allsopp et al. 2003), most likely by diminishing the net rate of telomere shortening rather than fully counteracting telomere attrition (Vaziri et al. 1994). Reduced telomerase activity and exceptionally short telomeres have been documented in peripheral blood lymphocytes of DC patients with mutations in hTR or hTERT (Yamaguchi et al. 2003; Marrone et al. 2004; Vulliamy et al. 2004; Armanios et al. 2005; Cerone et al. 2005; Alter et al. 2007; Westin et al. 2007). A telomere-based disease mechanism is consistent with the generational anticipation observed for DC (Vulliamy et al. 2004; Armanios et al. 2005), since affected parents are expected to contribute shorter telomeres to the next generation. The dominant inheritance pattern of DC caused by hTR and hTERT mutations can be explained from haploinsufficiency of these telomerase components (Marrone et al. 2004; Vulliamy et al. 2004; Armanios et al. 2005).

The more severe X-linked recessive form of DC is due to mutations in the dyskerin gene (DKC1) (Heiss et al. 1998), and an autosomal recessive form of DC has been shown recently to be due to mutations in NOP10 (Walne et al. 2007). Dyskerin and NOP10 bind H/ACA RNAs, which contribute to a wide variety of cellular processes, including ribosome biogenesis, pre-mRNA splicing, and telomerase biogenesis (Meier 2006). Observations on 
mice with a lesion in the DKC1 locus have been interpreted as evidence that DC is due to a defect in ribosome biogenesis rather than telomere dysfunction (Ruggero et al. 2003). On the other hand, dyskerin binds hTR, promotes telomerase biogenesis, and is associated with active human telomerase (Mitchell et al. 1999; Mochizuki et al. 2004; Cohen et al. 2007). Furthermore, diminished telomerase activity and telomere length defects have been demonstrated for DC cases due to mutations in dyskerin and NOP10 (Mitchell et al. 1999; Wong et al. 2004; Wong and Collins 2006; Walne et al. 2007).

An additional complication in the context of a telomere-based etiology of DC is that telomerase has been proposed to have functions independent of telomere maintenance, including in stem cell regulation (Zhu et al. 1999; Stewart et al. 2002; Sarin et al. 2005). So far, mouse models have not yielded a decisive answer to the question whether DC is a disease of telomere dysfunction because mice lacking components of telomerase have failed to show the phenotypes typical of DC. Due to the large telomere reserve of Mus musculus musculus, mTR and mTERT null mice have no discernable phenotypes in the first generations (Blasco et al. 1997; Nikaido et al. 1999; Liu et al. 2000). When the telomeres become shortened in the later generations, the telomerase $\mathrm{KO}$ mice show prominent premature aging phenotypes consistent with stem cell depletion in highly proliferative organs (Lee et al. 1998; Rudolph et al. 1999, 2000). The phenotypes include testicular and ovarian atrophy, alopecia, hairgraying, ulcerative skin lesions, and atrophic villi in the duodenum of older mice. Late generation telomerase $\mathrm{KO}$ mice are also less tolerant to exogenously induced stress, such as treatment with 5-FU, skin laceration, and liver injury. Nonetheless, the hallmark of DC, progressive bone marrow failure, is not observed in late generation telomerase $\mathrm{KO}$ mice. Although the mice have slightly reduced levels of hematopoietic progenitors, they do not show histological signs of defects in the bone marrow, spleen, or thymus; they are not immunodeficient or anemic; and they have normal peripheral red and white blood cell counts and blood chemistry. Late generation telomerase knockout mice also lack the hyperpigmentation and nail dystrophy that are typical of DC, and their life span is only moderately reduced (18 mo vs. $24 \mathrm{mo}$ ). Even when the initial telomere length is curbed by using $M . m$. castaneus, telomerase deficiency did not give rise to overt DC phenotypes (Hao et al. 2005).

Here we report on a mouse model in which key characteristics of DC are induced by enhanced telomere degradation. Telomere shortening primarily occurs through nucleolytic attack on the 5' end of the chromosome, represented by the [CCCTAA]n telomeric strand (referred to as the C-strand). C-strand processing normally takes place with each cell division and serves to generate the $3^{\prime}$ overhang, which provides binding sites for essential telomeric proteins (Baumann and Cech 2001) and contributes to the formation of the t-loop structure (Griffith et al. 1999). We reported previously that the generation of the $3^{\prime}$ overhang is controlled by a member of the POT1 family of proteins, which are single-stranded telomeric DNA-binding proteins within shelterin (Hockemeyer et al. 2006), the complex that protects telomeres from the DNA damage response/de Lange 2005; Palm and de Lange 2008). Among the two mouse POT1 proteins, POT1a is essential, probably because in its absence, telomeres induce an ATR-dependent DNA damage response (Hockemeyer et al. 2006; Wu et al. 2006; Lazzerini Denchi and de Lange 2007). In contrast, mice lacking POT1b are viable but have telomeres with unusually long 3' overhangs, suggesting excessive C-strand degradation (Hockemeyer et al. 2006). We argued that if POT $1 \mathrm{~b}$ protects the $5^{\prime}$ ends of telomeres from degradation, POT1b-deficient cells and mice might experience accelerated telomere shortening and could thus provide an alternative approach to modulating telomere length in the mouse. Here we show that loss of POT1b results in telomere degradation in mouse cells and use POT1b KO mice to study the phenotypic consequences of this type of telomere length modulation.

\section{Results}

\section{POT1b protects telomeres from $C$-strand degradation}

To test whether the extended overhangs in POT1b-deficient mouse cells are caused by excessive nucleolytic degradation of the C-rich telomeric strand, we determined the effect of POT1b loss on telomere shortening. As reported previously, POT1b was inactivated either through insertion of a STOP cassette before exon 3 $\left(\mathrm{POT}_{1} \mathrm{~b}^{\mathrm{S} / \mathrm{S}}\right)$ or through deletion of exon $3\left(\mathrm{POT}^{-1 b^{-/-}}\right)$ (Hockemeyer et al. 2006). Both genotypes represent apparent null alleles of POT1b and the phenotypes of the cells and mice were indistinguishable. The alleles used in this study are identified in each experiment.

Telomere dynamics were studied in SV40-LT immortalized mouse embryo fibroblasts (MEFs) carrying conditional alleles of POT1b $\left(\mathrm{POT}_{1} \mathrm{~b}^{\mathrm{F} /-}\right.$ or POT $\left.1 \mathrm{~b}^{\mathrm{F} / \mathrm{F}}\right)$. As expected, Cre-mediated deletion of POT1b induced an increase in single-stranded telomeric DNA in telomeraseproficient $\left(\mathrm{mTR}^{+/+}\right)$and telomerase-deficient $\left(\mathrm{mTR}^{-/-}\right)$ cells (Fig. 1A; Supplemental Fig. 1A). In addition, POT1b deletion induced telomere shortening. Telomere shortening was apparent from examination of the bulk telomeres as well as the higher-molecular-weight (MW) species and occurred in cells with and without telomerase (Fig. 1A; Supplemental Fig. 1A). In contrast, deletion of POT1a did not affect telomere length (Supplemental Fig. 1A). These results are consistent with the idea that POT1b has a specific function in protecting telomeres from C-strand degradation.

Exol has been implicated in C-strand degradation in Saccharomyces cerevisiae (Maringele and Lydall 2002). We therefore tested whether Exol modulated the effects of POT $1 b$ deletion using POT $1 b^{\mathrm{F} / \mathrm{F}} \mathrm{Exol}^{-/-}$MEFs generated by crossing the pertinent genetically altered mice. Regardless of whether Exol was present, deletion of POT1b resulted in C-strand degradation as evidenced by 
A
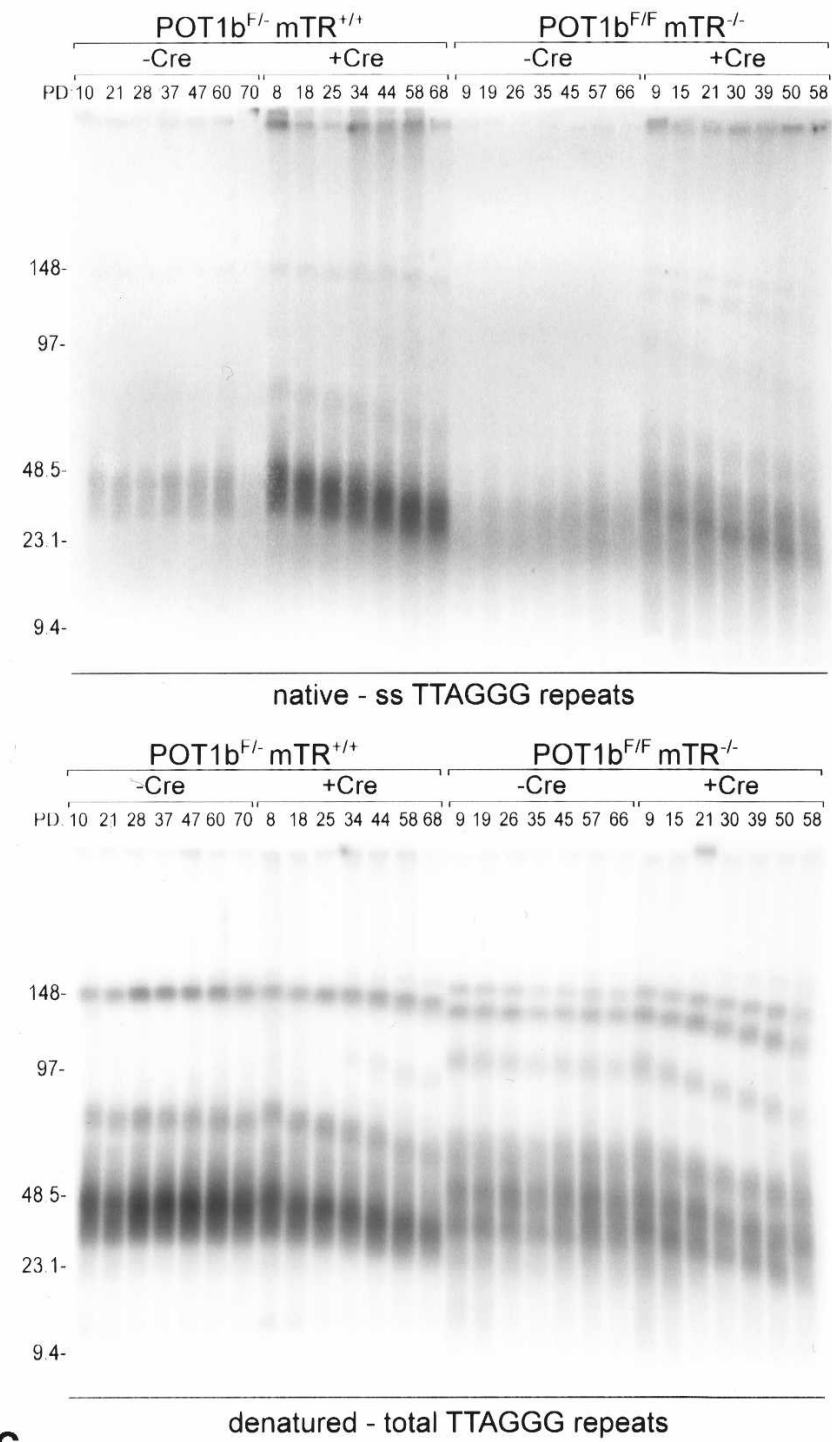

B
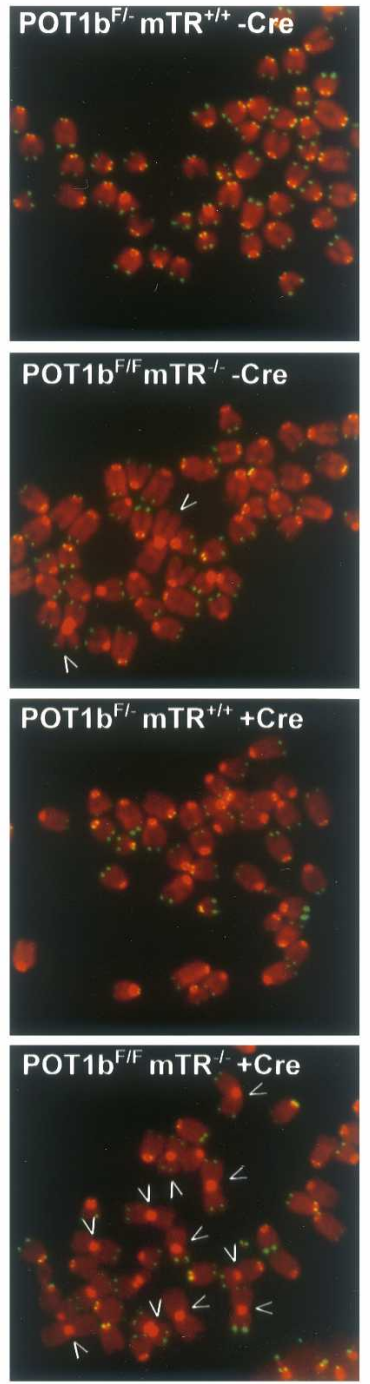

C

\begin{tabular}{|c|c|c|c|c|c|c|c|}
\hline \multirow[b]{2}{*}{ cell line and PD } & & \multirow{2}{*}{$\begin{array}{l}\text { chromosomes } \\
\text { scored }\end{array}$} & \multicolumn{2}{|c|}{$p$ arm fusions } & \multicolumn{2}{|c|}{$q$ arm fusions } & \multirow{2}{*}{$\begin{array}{l}\text { total number of fusions } \\
\text { (\% of chromosomes) }\end{array}$} \\
\hline & & & + tel & -tel & tel & -tel & \\
\hline POT $1 \mathrm{~b}^{\mathrm{F} /}-\mathrm{mTR}^{+/+}$ & PD90 & 1548 & 0 & 1 & 0 & 1 & $2(0.1 \%)$ \\
\hline POT1 $1 b^{F /-m T R} R^{+/+}+$Cre & PD86 & 1338 & 0 & 2 & 0 & 5 & $7(0.5 \%)$ \\
\hline POT1b $F / F_{m_{T R}} /-$ & PD85 & 1299 & 0 & 50 & 0 & 3 & $53(3.5 \%)$ \\
\hline РОТ1b $\mathrm{F} / \mathrm{F}_{\mathrm{mTR}^{-1-}}+\mathrm{Cre}$ & PD74 & 1505 & 3 & 74 & 1 & 23 & $101(6.7 \%)$ \\
\hline
\end{tabular}

Figure 1. Accelerated telomere shortening in POT1b-deficient cells. (A) Telomere length dynamics and telomeric overhangs of SV40LT-immortalized mTR-proficient and -deficient MEFs before and after deletion of POT1b with Cre. (Top) Size-fractionated MboI-digested DNA hybridized in gel under native conditions with a radiolabeled $[\mathrm{CCCTAA}]_{4}$-oligo detecting the $3^{\prime}$ overhang. (Bottom) The same gels after in situ denaturation of the DNA and rehybridization with the same probe. Numbers above the lanes reflect population doublings after introduction of pWZL-hygro-Cre (or the empty vector). MWs are indicated in kilobases on the left. (B) Telomere FISH analysis on metaphase chromosome spreads of the cells analyzed in $A$. PDs are given in C. DAPI-stained chromosomes are false colored the in red, and the telomere hybridization signal is shown in green. Arrows point at chromosome fusions. (C) Quantification of chromosome fusions detected in metaphases as shown in $B$.

an increase in the G-strand signal (Supplemental Fig. 1B). Therefore, the nuclease(s) responsible for C-strand deg- radation in POT1b-deficient cells remains to be determined. 
The telomere shortening associated with POT1b deficiency was obviously exacerbated in $\mathrm{mTR}^{-/-}$cells compared with their telomerase positive counterparts (Fig. 1A-C). However, even when telomerase was present, the telomeres shortened upon deletion of POT1b. Such failure in telomerase-mediated telomere maintenance in POT $1 b^{-/-}$cells could be explained if POT $1 b$ played a role in the telomerase pathway. Alternatively, the telomere shortening rate in POT $1 b^{-/-}$cells might simply exceed the maximal rate of telomere elongation by the telomerase present in these cells. The shortening rate of the largest class of telomeric fragments (MW $>60 \mathrm{~kb})$ was increased from 400 to $700 \mathrm{bp}$ per end per PD in POT1b ${ }^{-/-}$ cells lacking the mTR gene, suggesting that telomerase adds in the order of $300 \mathrm{bp}$ per end per PD in $\mathrm{POT}_{1} \mathrm{~b}^{-/-}$ $\mathrm{mTR}^{+/+}$cells. This telomere synthesis rate is close to the maximal rate of telomere elongation reported for mammalian telomerases (Barnett et al. 1993; McChesney et al. 2000; Loayza and de Lange 2003; Cristofari and Lingner 2006), suggesting that the rate of degradation of telomeres in POT $1 b^{-/-}$cells may be too great to be counteracted by telomerase.

In the absence of healing by telomerase, the degradation of the telomeric DNA in POT $1 b^{-1-} \mathrm{mTR}^{-1-}$ cells is expected to eventually disable the protective function of telomeres and elicit chromosome end fusions. Indeed, after the cultures had been propagated for $\sim 60 \mathrm{PD}$, the frequency of fused chromosomes was elevated in the POT $1 b^{-/} \mathrm{mTR}^{-/-}$cells compared with $\mathrm{mTR}^{-/-}$and POT $1 b^{-/-}$cells (Fig. 1C). As expected, most of the fusions in the POT $1 b^{-/-} \mathrm{mTR}^{-/-}$cells were due to short arm (Robertsonian) fusions that are stable in mitosis and therefore persist longer than fusions involving long-arm telomeres.

In summary, the data on telomere dynamics in MEFs indicate that POT1b deficiency leads to unusually rapid telomere shortening as a consequence of C-strand degradation, and that telomerase can counteract some, but not all, of this terminal sequence loss.

\section{Telomerase is essential in the context of POT1b deficiency}

Mice lacking either POT1b or telomerase are viable, have a normal life span, and are fertile (Blasco et al. 1997; Liu et al. 2000; Hockemeyer et al. 2006). The enhanced telomere shortening in the $\mathrm{POT}^{1} \mathrm{~b}^{-/-} \mathrm{mTR}^{-/-}$cells raised the possibility that diminished telomerase activity might affect the phenotype of POT1b deficiency and vice versa. To determine the effect of combined deficiency of POT1b and $\mathrm{mTR}$, we analyzed the offspring of intercrosses of $\mathrm{POT}_{1 b^{+/-}} \mathrm{mTR}^{+/-}$mice (Fig. 2A). All genotypes were represented at frequencies consistent with Mendelian inheritance of unlinked genes, with the exception of the POT $1 b^{-/-} \mathrm{mTR}^{-/-}$genotype, which was grossly underrepresented (one in 281 offspring; 15-fold less frequent than expected). Similarly, POT $1 \mathrm{~b}^{-/-} \mathrm{mTR}^{-/-}$mice were not recovered from an intercross of $\mathrm{POT}_{1} \mathrm{~b}^{+/-}$ $\mathrm{mTR}^{-/-}$breeding pairs that yielded 42 mice (expected number of doubly deficient mice $\sim 12$ ). Thus, the

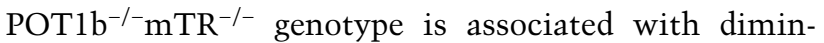

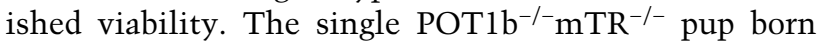
was runted, remained hairless, failed to thrive, and died 3 wk after birth (Fig. 2B). In contrast, POT $1 b^{-/-} \mathrm{mTR}^{+/-}$ mice survived to adulthood.

\section{Heterozygosity for mTR exacerbates POT1b ${ }^{-/-}$ phenotypes}

Comparison of POT $1 b^{-/-}$mice to wild-type and heterozygous littermates showed that both males and females were smaller and had a reduced body weight (Fig. 2C). The body weight of the POT $1 b^{-/-}$mice was further reduced in the context of mTR heterozygosity. An effect of mTR heterozygosity is consistent with previous reports indicating haploinsufficiency for the core telomerase components in mice and humans (Hathcock et al. 2002; Erdmann et al. 2004; Marrone et al. 2004; Armanios et al. 2005; Yamaguchi et al. 2005).

In addition to their reduced body weight, POT $1 b^{-/-}$ males showed a marked (approximately threefold) reduction in the size of the testis, and histological analysis revealed depletion of cells from the testicular lumen, including a reduction in spermatids (Fig. 2E,F). As expected from this phenotype, POT1b-deficient males became prematurely infertile, but when allowed to mate at a young age $(<6 \mathrm{mo})$, homozygous intercrosses of POT1bdeficient animals yielded offspring for five generations. The testicular atrophy was both more frequent and more severe in the $\mathrm{POT}^{-/-} \mathrm{mTR}^{+/-}$setting (Fig. 2D-F). $\mathrm{POT}_{1} \mathrm{~b}^{-/-}$mice also showed a defect in the small intestine as evidenced by apoptotic cells in a large percentage of the crypts (Fig. 2G,H) and this phenotype was also significantly worse in mice that lacked POT1b in the context of mTR heterozygosity.

\section{Cutaneous phenotypes}

All POT1b-deficient mice displayed striking hyperpigmentation of the paws, snout, ears, and tail (Fig. 3A,B). Hyperpigmentation developed when the mice were 3-4 mo old and appeared progressive with age (data not shown). The hyperpigmentation of the paws was more prominent in the $\mathrm{POT} 1 \mathrm{~b}^{-/-} \mathrm{mTR}^{+/-}$mice, and became visible at an earlier age (Fig. 3B). Histological analysis of hyperpigmented tails from two 8-mo-old POT1b $^{-/-}$ $\mathrm{mTR}^{+/+}$mice demonstrated a marked increase in the density of the melanosomes of the keratinocytes compared with age-matched wild-type controls (Fig. 3C). In addition, higher amounts of melanin were present in the stratum corneum (upper layers) of the epidermis suggesting higher melanin content in the melanosomes (Fig. 3C, arrowheads). Using both $\mathrm{H} \& \mathrm{E}$ and Fontana-Masson (melanin) stains, mutant mouse tails were found to have a markedly higher melanin content than the normal tails (Fig. 3C). After UV radiation of human skin, melanosomes become more densely distributed in an umbrella or "microparasol" over keratinocyte nuclei presumably 
A
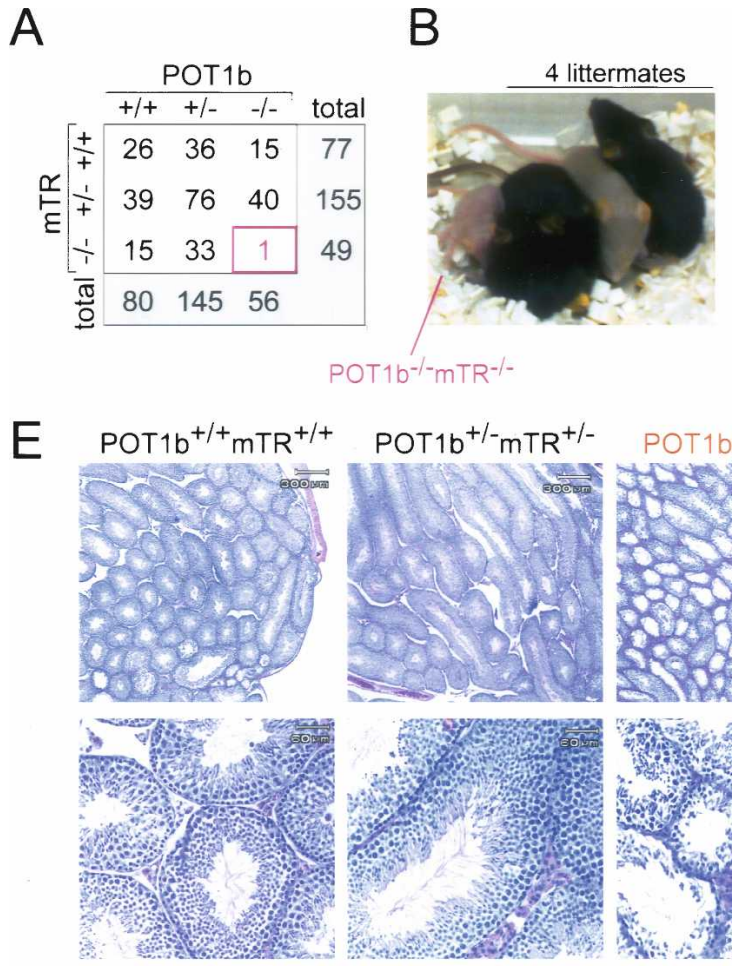

G

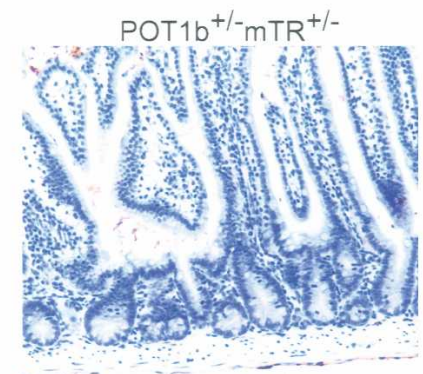

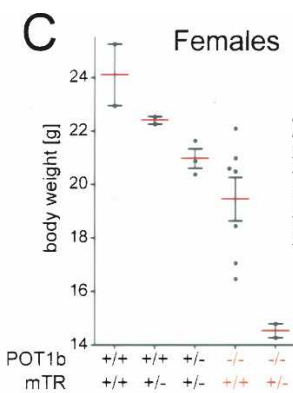
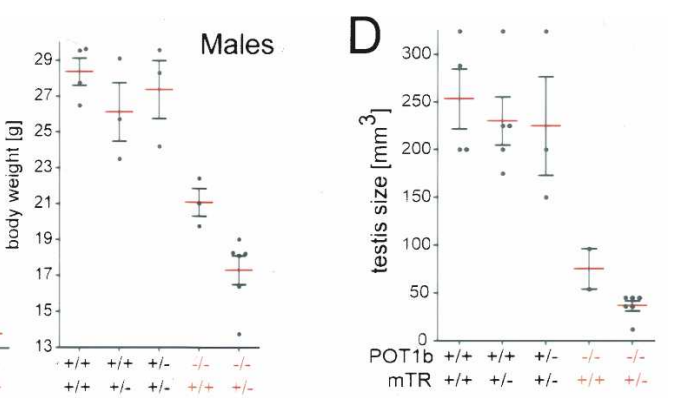

$\mathrm{F}$
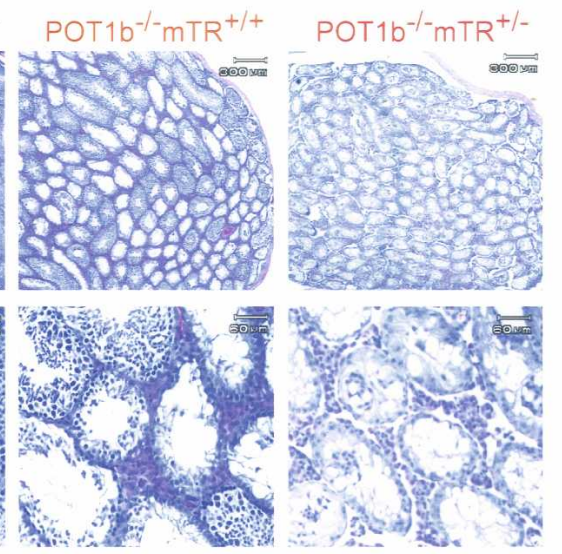

\begin{tabular}{|c|c|c|c|}
\hline \multirow[b]{2}{*}{ Genotype } & \multicolumn{3}{|c|}{ Testicular atrophy } \\
\hline & none & mild & severe \\
\hline POT1 $b^{+/+} \mathrm{mTR}^{+/+}$ & 5 & 0 & 0 \\
\hline POT1 $b^{+/+} \mathrm{mTR}^{+/-}$ & 5 & 0 & 0 \\
\hline POT1 $b^{+/-} \mathrm{mTR}^{+/-}$ & 5 & 0 & 0 \\
\hline POT1 $b^{-1-m_{T R}^{+/+}}$ & 1 & 2 & 0 \\
\hline POT1 $\mathrm{b}^{-/-} \mathrm{mTR}^{+/-}$ & 0 & 1 & 4 \\
\hline
\end{tabular}

\section{$\mathrm{H}$}
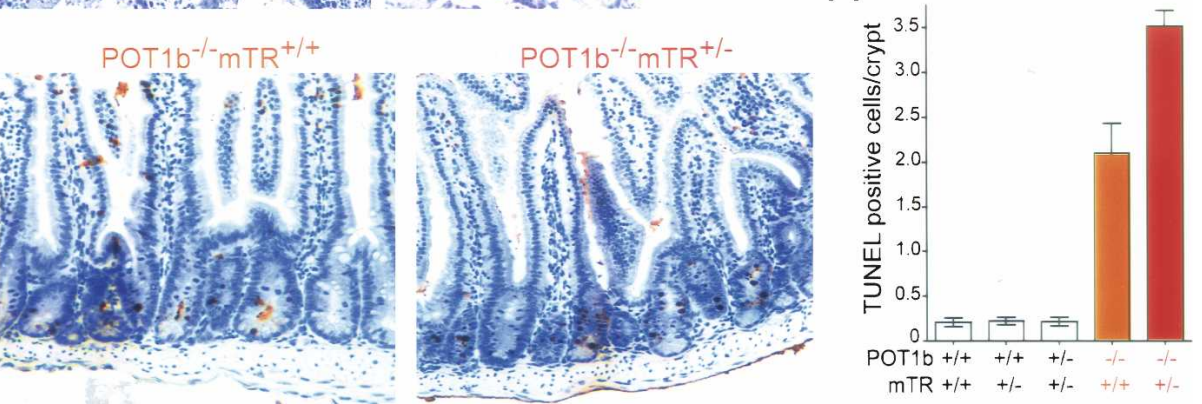

Figure 2. Curtailed telomerase exacerbates POT1b KO phenotypes. (A) Genotypes of 281 offspring from intercrosses between 15 $\mathrm{POT}_{1 \mathrm{~b}}{ }^{+/} \mathrm{mTR}^{+/-}$breeding pairs. (B) Photograph showing the single POT1b ${ }^{-/-} \mathrm{mTR}^{-/-}$animal born and its littermates. (C) Scatter plot of the bodyweights of adult $(>3 \mathrm{mo}$ ) female and male mice with the indicated genotypes. All animals were age-matched and derived from the intercross described in $A$. Error bars indicate the standard error of the mean. $(D)$ Quantification of testis size of age-matched males of the indicated genotypes. Error bars indicate the standard error of the mean. $(E)$ H\&E stained testis sections at two magnifications. Mice as in $A .(F)$ Incidence of testicular atrophy in mice of the indicated genotypes. Grading is based on H\&E staining as shown in $E$. $(G)$ TUNEL assay on H\&E-stained sections from the small intestine of age-matched mice of the indicated genotypes. (H) Quantification of apoptotic cells in the small intestines based on TUNEL staining of age-matched mice with the indicated genotypes

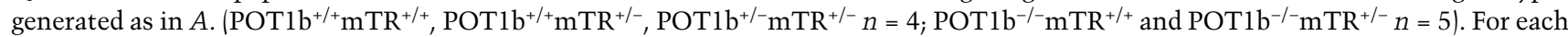
animal $>60$ crypts were analyzed. Error bars indicate the standard error of the mean.

in an effort to shield DNA from further damage (Gates and Zimmermann 1953; Byers et al. 2003). The increased melanosome content of the mutant mice share this "microparasol" distribution, suggesting a role for DNA damage in the generation of the increased pigmentation.

In addition to hyperpigmentation, DC patients present with nail dystrophy. Nails were examined in detail in a cohort of 10-mo-old POT1b KO mice representing the fifth generation of POT $1 b^{\mathrm{S} / \mathrm{s}}$ intercrosses and compared with age-matched wild-type controls (Fig. 3D). Among the POT1b KO mice, $\sim 25 \%$ had developed nail abnormalities on one or more digits while none of the control animals $(n=25)$ displayed nail malformations. Further analysis will be needed to assess the condition of the nails in younger POT1b-deficient animals. In particular, the $\mathrm{POT}^{-1-} \mathrm{mTR}^{+/-}$mice may have died before nail dystrophy became an overt phenotype (see below).

Progressive bone marrow failure and reduced life span

All POT $1 b^{-/-} \mathrm{mTR}^{+/-}$mice developed a severe defect in the bone marrow (Fig. 4). Peripheral blood cell counts showed significant pancytopenia with severe leukocytopenia (lymphopenia, neutropenia, and monocytopenia), thrombocytopenia, and mild anemia (Fig. 4A). Bone marrow from the femur and vertebrae was examined histo- 
A
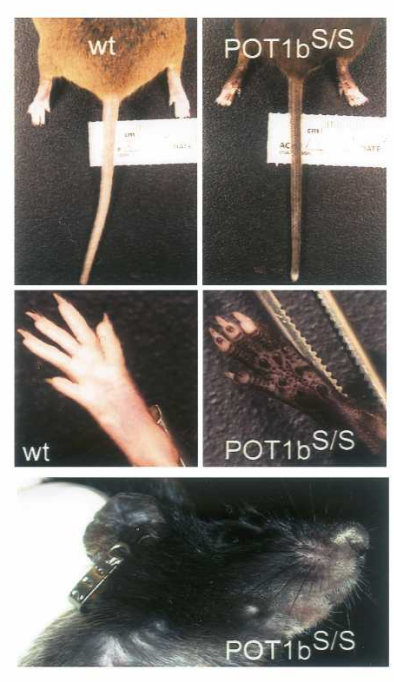

B

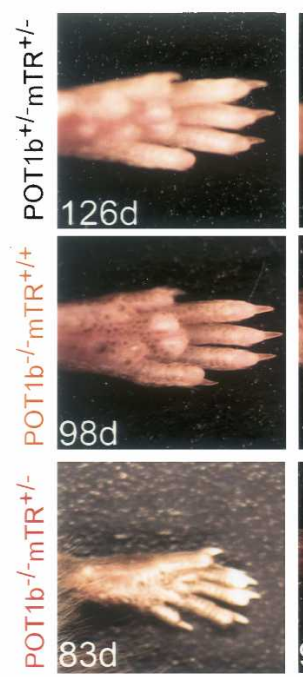

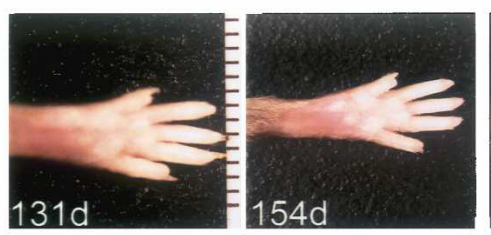
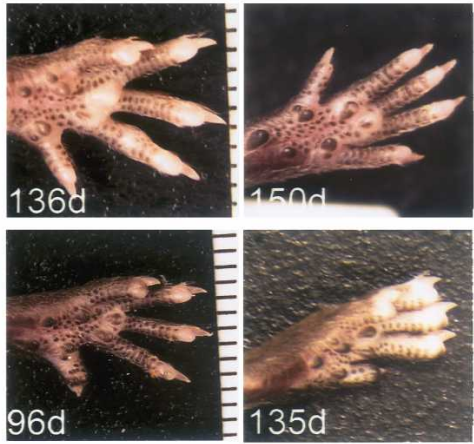
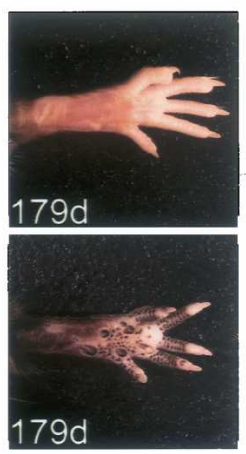

$179 d$
C
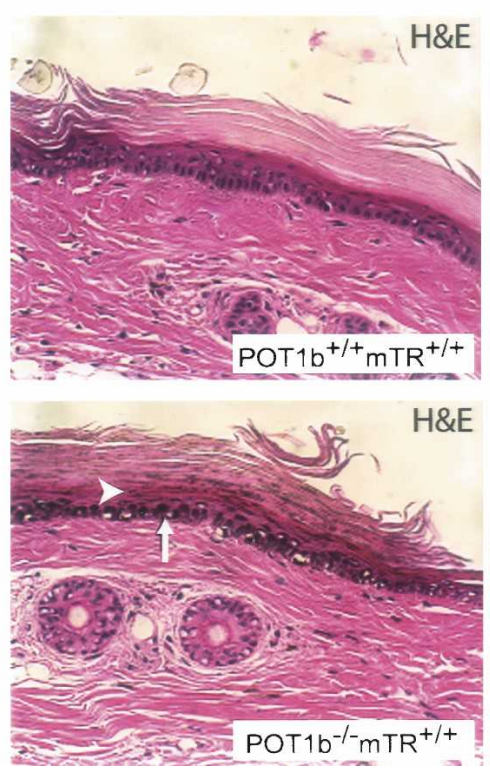
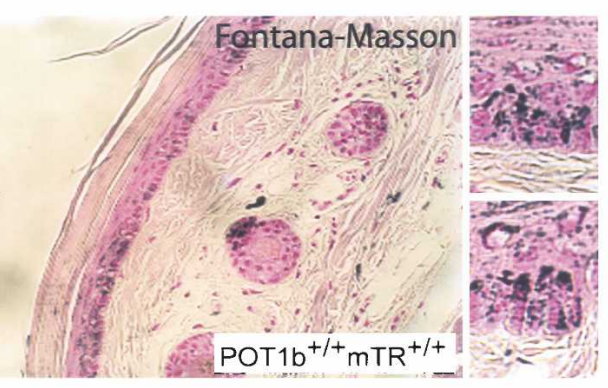

D

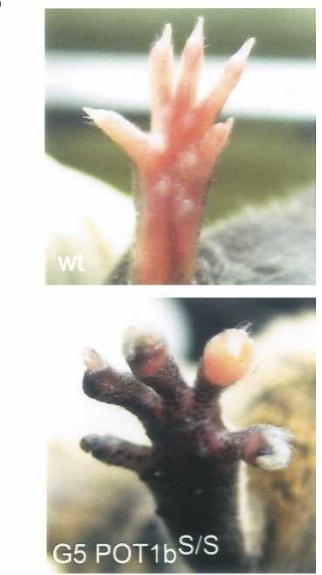

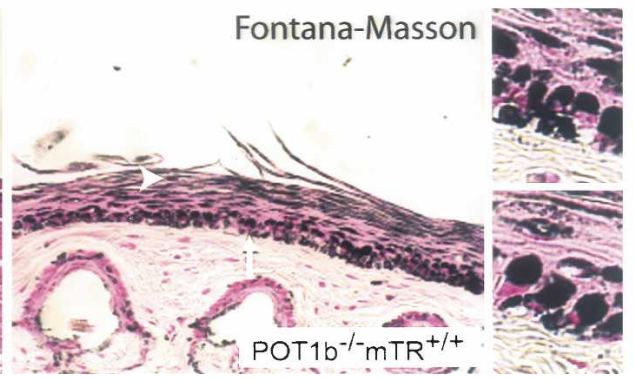

Figure 3. Cutanous phenotypes. (A) Photographs of POT $1 \mathrm{~b}^{\mathrm{s} / \mathrm{s}}$ and age-matched control animals showing hyperpigmentation on the snout, ears, tail, and paws of POT1b ${ }^{\mathrm{S} / \mathrm{s}}$ animals. $(B)$ Hyperpigmentation of the paws of mice with the indicated genotypes and ages. $(C)$ $\mathrm{H} \& \mathrm{E}$ and Fontana-Masson staining of tail sections of 8-mo-old mice with the indicated genotypes. Arrows indicate the increased deposition of melanosomes over the nuclei of the hyperpigmented mouse tail sections. Arrowheads indicate retention of the melanin in the stratum corneum. Enlarged images of the Fontana-Masson staining of tail sections of POT1b ${ }^{-/-}$and wild-type mice are shown at right. (D) Photographs showing abnormal nails on one paw of an 11 -mo-old G5 POT1 ${ }^{\mathrm{s} / \mathrm{s}}$ mouse. (Top) The wild-type control is age-matched.

logically, and revealed marked attrition with replacement of hematopoietic precursor cells of all recognizable hematopoietic lineages (myeloid, erythroid, and megakaryocytic) by stromal adipose tissue (Fig. 4B; Supplemental Fig. 2A). This bone marrow defect was also observed in a cohort of POT $1 b^{\mathrm{S} / \mathrm{S}} \mathrm{mTR}^{+/-}$mice (Supplemental Fig. 2A,B). When examined at 3 mo of age, POT1b ${ }^{-/-}$ $\mathrm{mTR}^{+/-}$mice also had abnormal spleen architecture with decreased lymphoid population in the white pulp, as demonstrated by immunohistochemical staining for the lymphoid marker B220, accompanied by increased erythropoiesis as indicated by expansion of the Ter-119marked red pulp (Fig. 4C). Such extramedullary erythro- poiesis may explain why the anemia in these mice is not more severe.

In comparison with their $\mathrm{POT} 1 \mathrm{~b}^{+/-} \mathrm{mTR}^{+/-}$littermates who thrived, POT $1 \mathrm{~b}^{-/-} \mathrm{mTR}^{+/-}$mice progressively deteriorated and died $\sim 4-5$ mo of age. The median survival of the POT $1 b^{-/-} \mathrm{mTR}^{+/-}$mice was $135 \mathrm{~d}$, a significant reduction in life span compared with telomerase-deficient mice or mice lacking POT1b (Fig. 4D). Similarly, POT $1 b^{\mathrm{S} / \mathrm{S}} \mathrm{mTR}^{+/-}$mice had a severely shortened life span of $147 \mathrm{~d}$ (Supplemental Fig. 2C). The significant reduc-

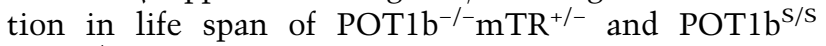
$\mathrm{mTR}^{+/-}$mice is likely due to the pancytopenia associated with bone marrow failure. 
A
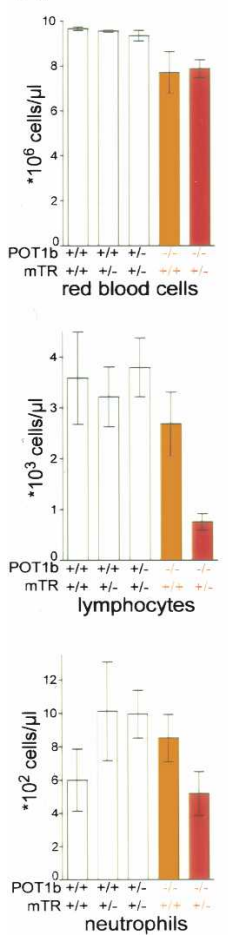

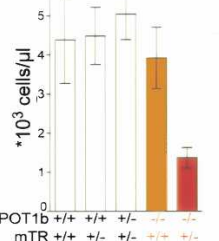

white blood cells
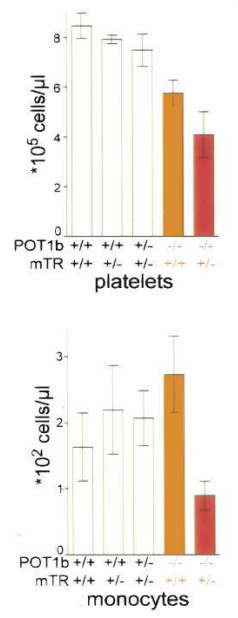

B

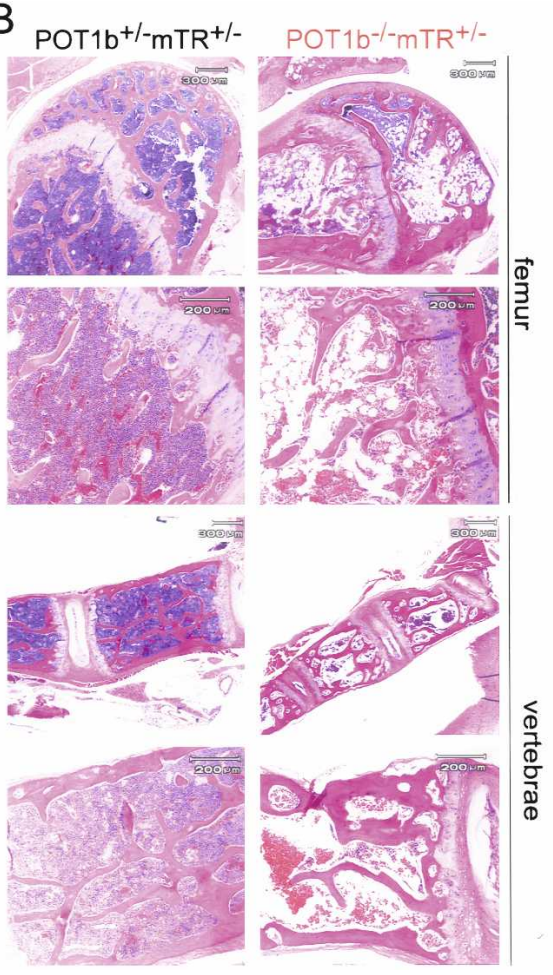

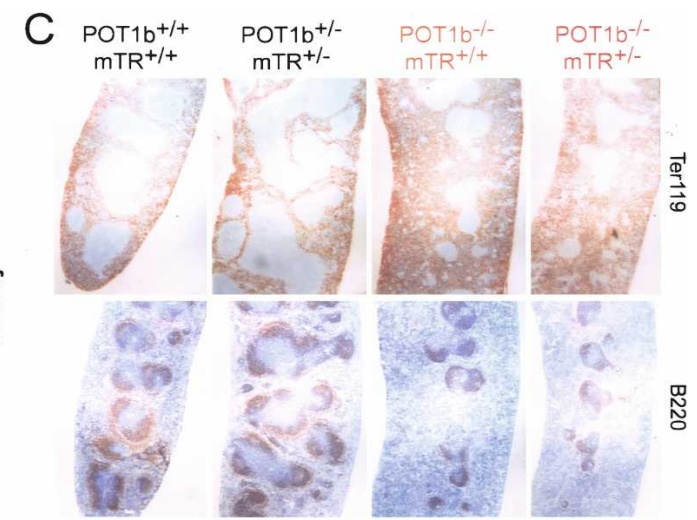

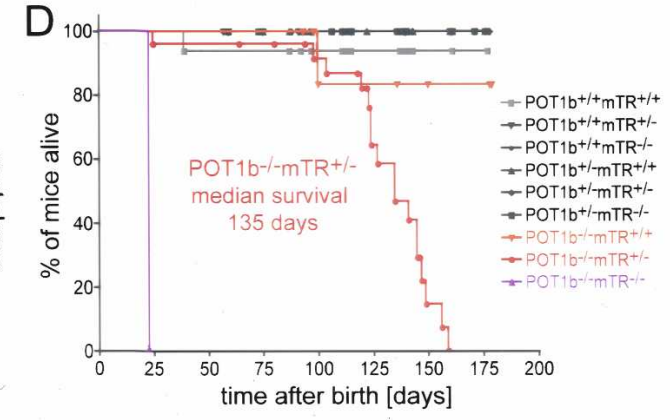

Figure 4. Bone marrow failure and premature death in $\mathrm{POT}^{-1 /-} \mathrm{mTR}^{+/-}$mice. $(A)$ Peripheral blood counts of age-matched mice with the indicated genotypes $\left(\mathrm{POT}_{1} \mathrm{~b}^{+/+} \mathrm{mTR}^{+/+}, n=6\right.$, average age: $149 \mathrm{~d}$; POT1b ${ }^{+/+} \mathrm{mTR}^{+/-}, n=5$, average age: $132 \mathrm{~d}_{\text {; POT1b }} \mathrm{P}^{+/-} \mathrm{mTR}^{+/-}$,

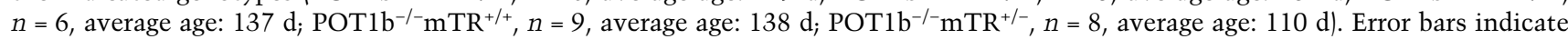

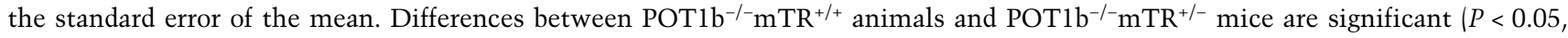
upaired $t$-test) for all parameters except for the red blood cells counts. (B) H\&E staining of bone marrow section of a 121-d-old $\mathrm{POT} \mathrm{b}^{+/-} \mathrm{mTR}^{+/-}$mouse (left panels) and an 83-d-old POT1b ${ }^{-/} \mathrm{mTR}^{+/-}$mouse (right panels). (C) Immunohistochemical staining of B220 and Ter119 in spleen sections of mice with the indicated genotypes. (age: POT $1 \mathrm{~b}^{+/+} \mathrm{mTR}^{+/+}$and POT1b $\mathrm{b}^{-/-} \mathrm{mTR}^{+/+}$animals $179 \mathrm{~d}$, $\mathrm{POTl}^{+/-} \mathrm{mTR}^{+/-}$and POT1b ${ }^{-/} \mathrm{mTR}^{+/-}$animals $\left.121 \mathrm{~d}\right) .(D)$ Kaplan-Meyer survival plot of mice derived from a heterozygous intercross of $\mathrm{POT}_{1} \mathrm{~b}^{+/-} \mathrm{mTR}^{+/-}$mice (see Fig. 2A). POT1b ${ }^{-/-} \mathrm{mTR}^{+/-}$mice die prematurely compared with the controls $(P<0.0001$, based on Log rank test).

Because of the severe bone marrow phenotype in the $\mathrm{POT}_{1} \mathrm{~b}^{-/} \mathrm{mTR}^{+/-}$mice, we analyzed the status of the telomeres in this tissue by Q-FISH (Fig. 5A). The bone marrow of 3-mo-old POT1b proficient mice, either with or without $\mathrm{mTR}$, showed the considerable telomere reserve typical of the genetic background of the mice (C57BL/6). POT1b-deficient mice containing normal levels of telomerase had a significant reduction of telomere length, consistent with the accelerated telomere shortening observed in MEFs (Fig. 1). The telomeres in the bone marrow of the POT1 $\mathrm{b}^{-/} \mathrm{mTR}^{+/-}$mice were further reduced in length. The shortening of the telomeres in these mice was also obvious from the occurrence of signal free ends in metaphase spreads (Fig. 5A,B). Furthermore, bone marrow chromosome spreads showed an increase in the frequency of chromosome end fusions (Fig. 5C), indicating considerable telomere dysfunction in this tissue.

\section{Discussion}

Our data indicate that key aspects of DC can be modeled in mice by inducing telomere degradation. Mouse mod- els for DC are needed to gain insight into the etiology of the disease and to evaluate new treatment strategies. Mouse telomeres recapitulate most aspects of human telomere biology, although differences in telomerase regulation, the telomere damage response pathway, and the composition of shelterin have been noted (Prowse and Greider 1995; Smogorzewska and de Lange 2002; Jacobs and de Lange 2004; Hockemeyer et al. 2006, 2007). By far the greatest challenge in generating mouse models for human telomere biology is the large telomere reserve of standard laboratory mice (subspecies M. m. musculus), which can sustain several generations in absence of telomerase (Blasco et al. 1997). In later generations, telomerase knockout mice show the impact of telomere dysfunction on several organs, yet the mice do not develop most of the characteristic symptoms of DC. The engineered telomere degradation in POT1b-deficient mice provides a first step toward a genuine DC model (Fig. 6). POT1b-deficient mice, in particular in the context of limiting telomerase activity, represent the most severe and lethal aspect of DC: progressive bone marrow failure. In addition, the POT1b-deficient mice show two features typical of DC: hyperpigmentation and nail ab- 
Hockemeyer et al.

A
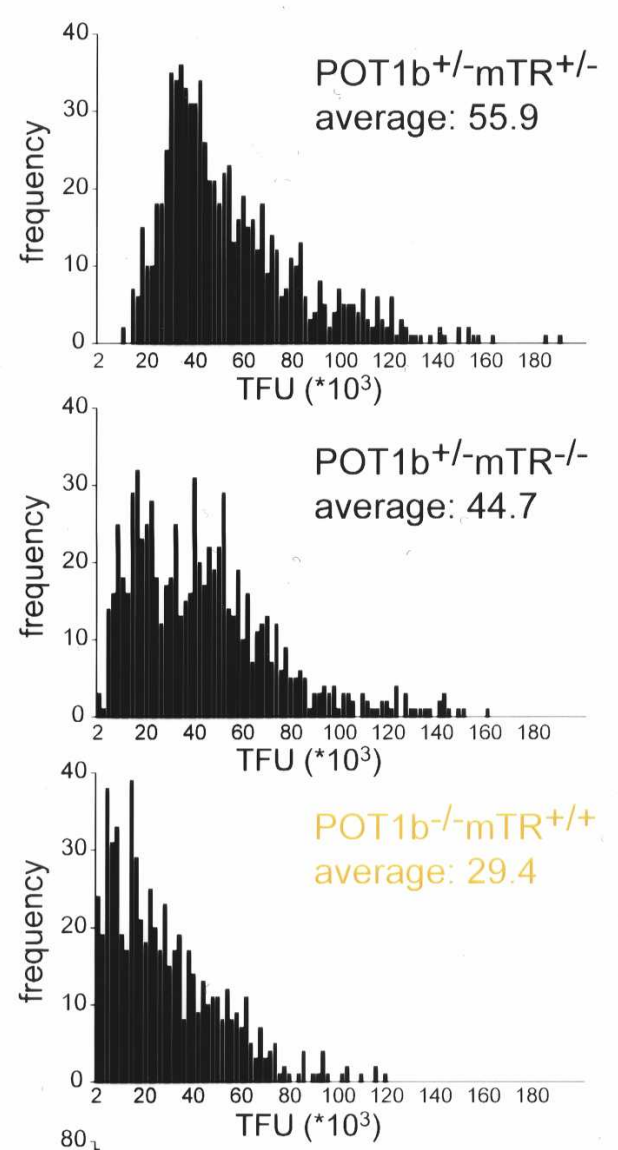

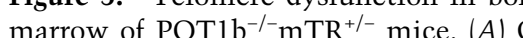
FISH analysis of the metaphases isolated from bone marrow of 3-mo-old littermates with the indicated genotypes. The $X$ axis shows telomere fluorescence hybridization intensity (TFU), the $Y$ axis shows the frequency of chromosomes ends with the indicated TFUs. Average TFU values are indicated in each panel. (B) Telomere FISH analysis of metaphases isolated from the bone marrow of mice (3-mo-old littermates) with the indicated genotypes. DAPI stained chromosomes are false colored in red and the telomere hybridization signal is shown in green. $(C)$ Quantification of chromosome abnormalities detected in metaphases as shown in B. Controls represent pooled data obtained from bone marrow samples of two POT1b ${ }^{+/-}$ $\mathrm{mTR}^{+/-}$, two POT $1 \mathrm{~b}^{+/-} \mathrm{mTR}^{-/-}$, and two $\mathrm{POT} \mathrm{b}^{-/-} \mathrm{mTR}^{+/+}$mice. tel ${ }^{+}$and tel ${ }^{-}$indicate fusions with and without telomeric FISH signals at the fusions sites, respectively.

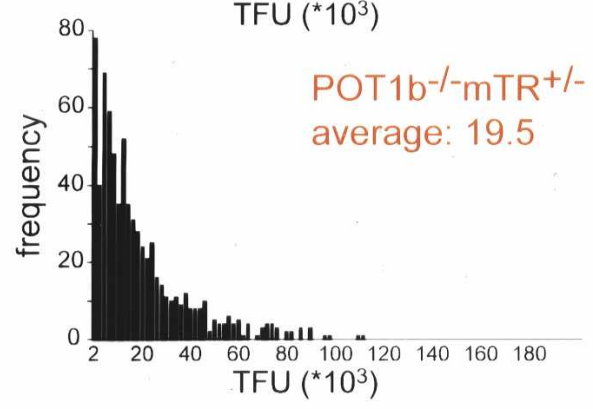

C
B
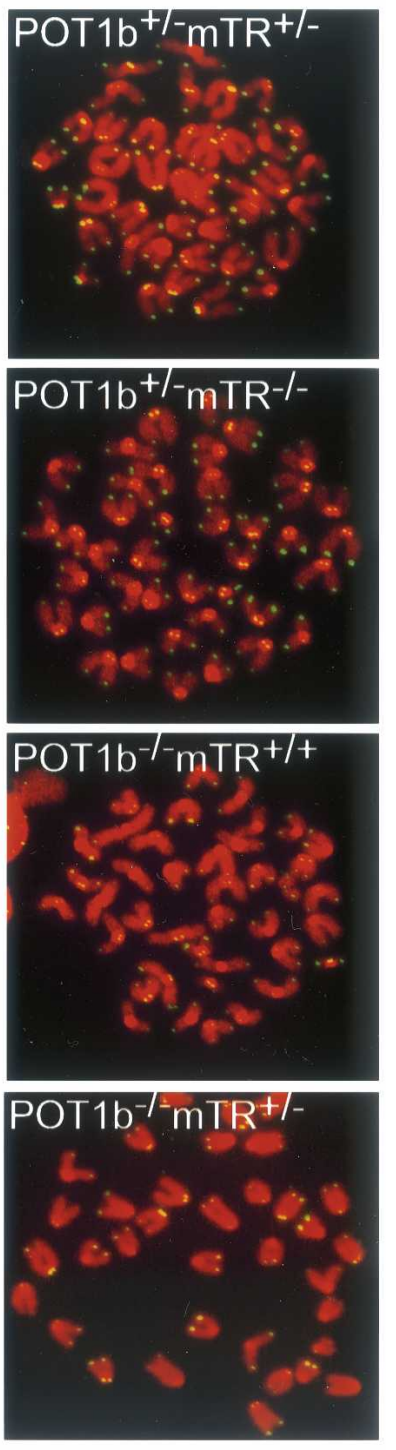

\begin{tabular}{lccccc}
\hline & $\begin{array}{c}\text { Chromosomes } \\
\text { scored }\end{array}$ & $\begin{array}{c}p \text { arm fusions } \\
\text { tel+ }\end{array}$ & \multicolumn{2}{c}{ tel- } & arm fusions \\
tel+ & tel- \\
\hline Controls $(n=6)$ & 3504 & 0 & 0 & 0 & 0 \\
POT1 ${ }^{-1-}$ mTR $^{+/-}(n=4)$ & 3156 & 12 & 38 & 0 & 2 \\
\hline
\end{tabular}

normalities. Importantly, several DC phenotypes arise in a setting with normal telomerase activity. This provides a strong argument that DC is due to telomere dysfunction rather than a defect in ribosome biogenesis or a deficiency in of one of the nontelomeric functions ascribed to telomerase.

\section{Engineering telomere degradation}

A general attribute of telomeres in unicellular organisms is that they render chromosome ends resistant to nucleolytic attack. A POT1 ortholog from ciliates protects telomere termini from nucleases in vitro /Gottschling and 


\begin{tabular}{|c|c|c|c|}
\hline \multirow[b]{2}{*}{ DC } & \multicolumn{3}{|c|}{ mice with telomere length defects } \\
\hline & $\mathrm{G}_{6} \mathrm{mTR}^{-1-\mathrm{a}}$ & POT1b ${ }^{-1-}$ & G1 POT1b ${ }^{-/-} \mathrm{mTR} R^{+/-}$ \\
\hline $\begin{array}{l}\text { fatal bone marrow } \\
\text { failure }\end{array}$ & not observed & not observed & $\begin{array}{l}\text { fatal bone marrow } \\
\text { failure }\end{array}$ \\
\hline reduced life-span & 18 months & not observed & 4 months \\
\hline $\begin{array}{l}\text { severe } \\
\text { pancytopenia }\end{array}$ & not observed & $\begin{array}{l}\text { moderate } \\
\text { pancytopenia }\end{array}$ & $\begin{array}{l}\text { severe } \\
\text { pancytopenia }\end{array}$ \\
\hline $\begin{array}{l}\text { cutanous reticulated } \\
\text { hyperpigmentation }\end{array}$ & not observed & hyperpigmentation & hyperpigmentation \\
\hline nail dystrophy & not observed & $\begin{array}{l}\text { nail dystrophy } \\
\text { with age (G5) }\end{array}$ & $\mathbf{b}$ \\
\hline $\begin{array}{l}\text { premalignant } \\
\text { leukoplakia }\end{array}$ & ND & ND & NDD \\
\hline $\begin{array}{l}\text { atrophy of the } \\
\text { intestinal mucosa }\end{array}$ & $\begin{array}{l}\text { moderate intestinal } \\
\text { apoptosis }\end{array}$ & $\begin{array}{l}\text { moderate intestinal } \\
\text { apoptosis }\end{array}$ & $\begin{array}{l}\text { severe intestinal } \\
\text { apoptosis }\end{array}$ \\
\hline infertillity & infertillity & $\begin{array}{l}\text { male infertillity } \\
\text { with age }\end{array}$ & $\begin{array}{l}\text { male infertillity } \\
\text { with age }\end{array}$ \\
\hline
\end{tabular}

$a_{\text {phenotypes are exacerbated and/or occur in earlier generations in genetic }}$ backgrounds and subspecies with shorter telomeres (e.g. M. m. castaneus)

$b_{\text {analysis limited by reduced life-span }}$
Figure 6. Telomere length manipulation in the mouse and comparison with DC Comparison of the symptoms found in DC patients with the phenotypes observed in the late generation of telomerase knockout mice and $\mathrm{POT}_{1 \mathrm{~b}}{ }^{-/-}$and $\mathrm{POT}_{1 \mathrm{~b}} \mathrm{~b}^{-/} \mathrm{mTR}^{+/-}$mice.
Zakian 1986). Similarly, Cdc13, the single-stranded telomeric DNA-binding protein of budding yeast, prevents degradation of the 5 '-ended telomeric DNA strand by ExoI (Maringele and Lydall 2002), and fission yeast lacking Pot 1 show rapid loss of the telomeric DNA (Baumann and Cech 2001).

Our data suggest that mammalian telomeres conform in this regard since deletion of POT1b results in resection of the C-rich telomeric strand and accompanying telomere shortening. Previous data indicates that POT1b does not control other aspects of telomere protection. For instance, POT1b-deficient cells do not show an immediate DNA damage response at telomeres nor do they display inappropriate DNA repair reactions at chromosome ends (Hockemeyer et al. 2006). These protective aspects depend on other components of shelterin, including POT1a (Hockemeyer et al. 2006; Lazzerini Denchi and de Lange 2007). Thus, POT1b provides a specific tool to induce telomere degradation without immediate effects on the essential aspects of telomere function.

\section{Manipulating telomere length in the mouse}

The length of mouse telomeres has been primarily manipulated by enforcing telomere attrition through telomerase withdrawal. In the absence of telomerase, telomeres shorten at $\sim 4 \mathrm{~kb}$ per generation, reflecting attrition during the $\sim 20$ cell divisions separating the germline of one generation from the next (Blasco et al. 1997). Within each generation, additional attrition will occur during the cell divisions required to form and maintain adult tissues. This process is likely to shorten telomeres to variable extents in different somatic cell types depending on their replicative history. However, the actual extent of telomere attrition in the murine soma is largely unknown. Telomere dysfunction is predicted to only occur in tissues in which sufficient cell divisions have occurred to deplete the telomere reserve provided in that generation. Therefore, the telomerase KO approach creates a window for telomere dysfunction to arise in a subset of tissues in the last viable generation. An improved version of this approach was recently developed using $M$. $m$. castaneus, a Mus musculus subspecies whose telomere length is substantially shorter and therefore accelerates the onset of telomere dysfunction by several generations (Hao et al. 2005). These approaches have provided important insights into the impact of telomere attrition on organ function and tumorigenesis.

The accelerated telomere shortening resulting from POT1b deficiency adds two important new aspects to manipulating telomere length in the mouse. First, the degradation of telomeres in $\mathrm{POT}_{1} \mathrm{~b}^{-/-} \mathrm{mTR}^{+/-}$mice is so extensive with each cell division that phenotypes arise in the first generation even within the context of the long telomeres typical of standard laboratory mice. This rapid onset of the phenotype represents a considerable gain in terms of experimental effort. Second, the degradation of telomeres in the POT $1 b^{-/-}$setting has shifted the spectrum of the tissues that are affected. Importantly, the POT $1 b^{-/-} \mathrm{mTR}^{+/-}$mice develop progressive bone marrow failure, a phenotype not seen in the telomerase knockout systems, presumably because their telomere reserve in the bone marrow is sufficient to sustain a minimal level of hematopoiesis, even in the last viable generation. Conversely, the $\mathrm{POT}_{1} \mathrm{~b}^{-/-} \mathrm{mTR}^{+/-}$mice do 
not show hair-graying or alopecia, which is observed in late generation $\mathrm{mTR}^{-/-}$mice. The simplest explanation for this difference in affected organs in the two experimental systems is to assume that the extent of telomere degradation in absence of POT1b is affected by both the number of cell divisions and the level of the nuclease(s) that resects the $5^{\prime}$ end of the telomeres. Thus, the hematopoietic system may be more severely affected in the $\mathrm{POT}^{-/-}$setting than in the $\mathrm{mTR}^{-/-}$mice due to higher levels of the culprit nuclease in hematopoietic stem cells. Conversely, cell types with less nuclease activity or higher telomerase activity will be protected from telo-

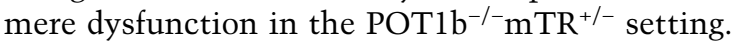

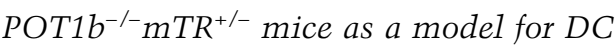

The findings with the POT $1 b^{-/-} \mathrm{mTR}^{+/-}$and POT $1 \mathrm{~b}^{\mathrm{s} / \mathrm{s}}$ mice strongly suggest that several of the DC phenotypes, including bone marrow failure, hyperpigmentation, and nail dystrophy, are indeed due to telomere failure, rather than a defect in ribosomal biogenesis. The hyperpigmentation in the POT $1 b^{-1-}$ mice could be explained from the induction of a DNA damage response after depletion of the telomere reserve in a subset of cells. Recent data have shown that in addition to UV, other forms of DNA damage can elicit a p53-dependent tanning response in the skin (Cui et al. 2007). Although we did not test the requirement for p53 in the hyperpigmentation in the $\mathrm{POT}_{1 \mathrm{~b}}{ }^{-/-}$mice, the formation of melanosome "microparasols" that cap over the nuclei suggests that the phenotype is similar to the tanning response. With regard to the nail abnormalities, we imagine that one possibility is that a stem cell population required for normal nail growth is affected by the accelerated telomere loss.

It will be of interest to study the occurrence of additional DC characteristics, including oral leukoplakia, cancer predisposition, and lung fibrosis in this setting, since this could clarify the contribution of telomere dysfunction to these symptoms. In order to study these and other late-onset symptoms, it may be necessary to develop a system in which the premature death due to bone marrow failure is prevented (e.g., by bone marrow transplantation).

An obvious concern with the $\mathrm{POT}^{-/-} \mathrm{mTR}^{+/-}$model for $\mathrm{DC}$ is that the phenotypes are due to a mutation in a gene that only occurs as such in rodents (Hockemeyer et al. 2006). However, our recent data indicate that the critical protein domains of POT1b required to block telomere degradation are functionally conserved in human POT1, suggesting that human POT1 can similarly block telomere degradation in human cells (W. Palm, D. Hockemeyer, and T. de Lange, unpubl.). Given this functional conservation, POT1 should be considered in the genetic analysis of DC patients lacking mutations in telomerase, dyskerin, or NOP-10. Our data predicts the possibility of DC due to a dissociation of function mutation in POT1 that unleashes $\mathrm{C}$-strand resection without affecting the repression of ATR. Excessive C-strand resection is expected to result in inappropriate telomere shortening with accompanying phenotypic consequences. Interest- ingly, a recent report described mutations in TIN2 in several DC cases, suggesting that alterations in shelterin can indeed contribute to this disease (Savage et al. 2008).

\section{Materials and methods}

\section{Mouse strains and MEFs}

POT $1 b^{\mathrm{S} / \mathrm{s}}$ mice and the crosses of POT $1 \mathrm{~b}^{\mathrm{F} / \mathrm{F}}$ to the $\mathrm{mTR}^{-/+}$mice were described previously (Hockemeyer et al. 2006). As no significant differences between POT $1 b^{+/+}$and POT $1 b^{\mathrm{S} /+}$ mice were detectable, the data from these cohorts were pooled and used as controls. POT $1 b^{-/-}$mice were generated by crossing mice carrying the POT1b FLOX allele to the germline deleting B6.FVB$\mathrm{Tg}$ (EIIa-cre)C5379Lmgd/J mouse strain (Jackson Laboratories). Chimeric mice with germline deletion of the Floxed allele were crossed to C57BL/6J mice to remove the Cre transgene. The resulting $\mathrm{POT}_{1 \mathrm{~b}} \mathrm{~b}^{+/-}$mice were crossed to $\mathrm{mTR}^{+/-}$mice to generate POT1b ${ }^{+/-} \mathrm{mTR}^{+/-}$mice. All analysis was performed exclusively on mice obtained from heterozygous intercrosses of $\mathrm{POT}^{1} \mathrm{~b}^{+/-} \mathrm{mTR}^{+/-}$mice. Offspring of $>15$ breeding pairs were used in the analysis. Exo1 ${ }^{-/-}$mice were provided by W. Edelmann and crossed to the POT $1 b^{\mathrm{F} / \mathrm{F}}$ mice to introduce the conditional POT1b allele. MEFs were derived and cultured as described previously (Hockemeyer et al. 2006). POT1b mice and MEFs were genotyped by PCR as described previously (Hockemeyer et al. 2006). mTR-deficient mice and MEFs were genotyped by PCR with the following primers: 5 '-TTCTGACCAC CACCAACTTCAAT-3', 5'-CTAAGCCGGCACTCCTTACA AG-3', and 5'-GGGGCTGCTAAAGCGCAT-3'. Exo1 ${ }^{-/-}$mice and MEFs were genotyped by PCR with primers $5^{\prime}$-CTCTT GTCTGGGCTGATATGC-3', 5'-ATGGCGTGCGTGATGTT GATA-3', and 5'-AGGAGTAGAAGTGGCGCGAAGG-3' .

\section{Analysis of telomeric DNA}

Telomere fluorescence in situ hybridization, in-gel telomere overhang assays, and telomere length analyses were performed as described (Hockemeyer et al. 2006). Bone marrow cells for telomere length analysis were isolated from the femur by flushing with PBS. Cells were cultured in medium supplemented with $15 \%$ fetal calf serum and $200 \mathrm{ng} / \mathrm{mL}$ demecolcine (Sigma) for $2 \mathrm{~h}$. Cells were harvested and prepared for metaphase spreads and FISH analysis as described previously (van Steensel et al. 1998). Q-FISH analysis was performed as a blind study as described (Hao et al. 2005).

\section{Histology and immunohistochemistry}

For H\&E staining, 4-6 $\mu \mathrm{m}$ paraffin sections were rehydrated in water and placed in Harris Hematoxylin solution (Poly Scientific) for $2 \mathrm{~min}$. Slides were rinsed in water and in Clarifier 1 solution (Richard-Allan Scientific) for $10 \mathrm{sec}$. After another wash with water, slides were stained with Bluing Reagent (Richard-Allan Scientific) for $8 \mathrm{sec}$ and washed with tap water. After dipping the slides once in $95 \%$ ethanol, slides were incubated for $1 \mathrm{~min}$ in Eosin Y Alcoholic Working solution (Poly Scientific). Samples were dehydrated with serial washes of $70 \%, 95 \%$, and $100 \%$ ethanol, and sealed with a coverslip using Cytoseal XYL solution (Richard-Allan Scientific). All steps were performed at room temperature.

For detection of B220 and Ter-119, slides with tissue sections were heated for $30 \mathrm{~min}$ at $58^{\circ} \mathrm{C}$ to $60^{\circ} \mathrm{C}$ and afterward deparaffinized by sequential incubations in $100 \%, 95 \%$, and $70 \%$ etha- 
nol and water. Afterward, sections were incubated in $1 \%$ hydrogen peroxide in phosphate-buffered saline (PBS) for $15 \mathrm{~min}$ and rinsed in PBS. For Ter-119 staining the slides were microwaved in $10 \mathrm{mM}$ Sodium Citrate $(\mathrm{pH}$ 6.0) at a high-power setting for $15 \mathrm{~min}$. Slides were incubated for $30 \mathrm{~min}$ in $10 \%$ normal rabbit serum (MP Biomedicals) diluted in $2 \%$ BSA in PBS in a humid chamber. Next, sections were incubated with a 1:200 dilution of primary antibody (B220: CD45R/B220; Ter-119: Lys76; BD Pharmingen) in $2 \%$ BSA in PBS overnight at $4^{\circ} \mathrm{C}$ in a humid chamber. Sections were rinsed three times with PBS and incubated with a 1:100 dilution in PBS of a biotinylated mouseabsorbed anti-Rat IgG (Vector Labs) for $30 \mathrm{~min}$ at room temperature. Slides were rinsed three times in PBS and incubated for $30 \mathrm{~min}$ using the Avidin-Biotin Complex Elite kit (Vector Laboratories) using conditions provided by the manufacturer. After washing the slides three times with PBS, sections were stained with 3,3'-Diaminobenzidine (Sigma-Aldrich). Slides were washed with water and counterstained with hematoxylin. Afterward slides were dehydrated with three changes of $95 \%$ ethanol and $100 \%$ ethanol and mounted with coverslips.

For H\&E staining of skin sections, paraffin sections were processed using a Leica Autostainer XL. Sections were dried for 10 min and rehydrated with three changes of xylene $(3 \mathrm{~min}, 3 \mathrm{~min}$, and $1 \mathrm{~min}$ ), two changes of absolute alcohol ( $30 \mathrm{sec}, 20 \mathrm{sec}$ ), $95 \%$ alcohol $(30 \mathrm{sec})$, and deionized water $(30 \mathrm{sec})$. Sections were stained with Harris Hematoxylin solution for $8 \mathrm{~min}$. Samples were washed with running water $(1 \mathrm{~min})$ and Clarifier solution $(30 \mathrm{sec})$. Samples were washed with running water $(30 \mathrm{sec})$ and stained with Bluing Solution (30 sec). Samples were washed with running water $(30 \mathrm{sec})$, dehydrated with $95 \%$ alcohol $(30$ $\mathrm{sec})$, and stained with Eosin-Y (1 min). Slides were dehydrated with three changes of absolute alcohol $(30 \mathrm{sec})$ and cleared with three changes of xylene (20 sec). Finally, slides were mounted with synthetic resin.

For Fontana-Masson staining of skin sections, paraffin tail sections were deparaffinized and hydrated in distilled water. The slides were immersed $10 \%(\mathrm{w} / \mathrm{v})$ silver nitrate solution in a $56^{\circ} \mathrm{C}$ waterbath for $1-2 \mathrm{~h}$. The reaction was stopped when granules were dark brown and the background colorless. The sections were rinsed in distilled water and then immersed in $0.2 \%$ $(\mathrm{w} / \mathrm{v})$ gold chloride solution for $10 \mathrm{~min}$. The sections were rinsed in distilled water and then placed in $5 \%(\mathrm{w} / \mathrm{v})$ sodium thiosulfate solution for $5 \mathrm{~min}$. The sections were rinsed in distilled water and then counterstained in nuclear-fast red for 5 min. The slides were washed for $1 \mathrm{~min}$ in running water. The slides were dehydrated with two changes each of $95 \%$ and absolute alcohol and cleared with xylene. Finally, slides were mounted with synthetic resin.

\section{TUNEL assay}

TUNEL assays were performed essentially as described (Gavrieli et al. 1992). Slides with paraffin sections were heated for 30 min at $58^{\circ} \mathrm{C}-60^{\circ} \mathrm{C}$ and deparaffinized by three washes with xylene and rehydrated by three washes of $100 \%$ ethanol for $10 \mathrm{~min}$ each, three 3-min washes with $95 \%$ ethanol, and three 3-min washes with water. Sections were immersed in $10 \mathrm{mM}$ Tris- $\mathrm{HCl}$ (pH 8.0) for $5 \mathrm{~min}$ and incubated with $20 \mu \mathrm{g} / \mathrm{mL}$ proteinase $\mathrm{K}$ in $10 \mathrm{mM}$ Tris- $\mathrm{HCl}$ (pH 8.0) for $15 \mathrm{~min}$ in a humid chamber. Next, slides were washed in water four 4 times for 2 min each and incubated in $3 \% \mathrm{H}_{2} \mathrm{O}_{2}$ in PBS for $5 \mathrm{~min}$ at room temperature. Afterward, slides were washed three times with distilled water for $2 \mathrm{~min}$ each. Sections were incubated in $30 \mathrm{mM}$ Tris- $\mathrm{HCl}$, $140 \mathrm{mM}$ Na-Cacodylate, $1 \mathrm{mM} \mathrm{CoCl}_{2}(\mathrm{pH} 7.2)$, and terminal transferase reactions were performed in $0.1 \mathrm{M} \mathrm{Na}$-Cacodylate, $0.1 \mathrm{mM}$ DTT, $0.05 \mathrm{mg} / \mathrm{mL}$ BSA, $2.0 \mathrm{U} / \mu \mathrm{L}$ Terminal Transferase
(Roche), $0.1 \mathrm{nmol}$ Biotin-16-dUTP, and $2.5 \mathrm{mM} \mathrm{CoCl}_{2}$ (pH 7.2) at room temperature for $1 \mathrm{~h}$. Reactions were terminated with $300 \mathrm{mM} \mathrm{NaCl}$ and $30 \mathrm{mM} \mathrm{Na}$-citrate (pH 6.0), and slides were washed three times for 2 min with PBS. Slides were blocked with $2 \%$ BSA (Sigma-Aldrich) in PBS for $10 \mathrm{~min}$ in a humid chamber and washed three times 2 min each in PBS. Sections were incubated in Avidin-Biotin Complex Elite kit (Vector Labs) using conditions provided by the manufacturer for $30 \mathrm{~min}$ and washed with PBS three times for 5 min each. Afterward, sections were stained with 3,3'-Diaminobenzidine for $3 \mathrm{~min}$ and washed with water, and subsequently counterstained with hematoxylin and dehydrated before sealing with a coverslip.

\section{Acknowledgments}

We thank Margaret Strong and Carol Greider for performing the Q-FISH analysis and for critical discussion of this work. We are grateful to Devon White for expert mouse husbandry and technical help with mouse procedures. Diana Argibay is thanked for assistance with genotyping. Sean Rooney is thanked for help with isolation of bone marrow cells. Joe Susa and Dermpath Diagnostics are thanked for tissue processing. Winfried Edelman is thanked for a generous gift of the Exo1 ${ }^{-/-}$mice. We thank Monika Bessler, Phil Mason, Ronald DePinho, and members of the de Lange laboratory for helpful discussion. Nadya Dimitrova, Kristina Hoke, Eros Lazzerini Denchi, and Hiro Takai are thanked for technical assistance. D.H. was supported by a Cancer Research Institute Predoctoral Emphasis Pathway in Tumor Immunology Grant and Rockefeller University Graduate Program Funds. W.P. was supported by the Studienstiftung des deutschen Volkes. This work was supported by a grant from the NCI to T.d.L. (CA076027).

\section{References}

Allsopp, R.C., Morin, G.B., DePinho, R., Harley, C.B., and Weissman, I.L. 2003. Telomerase is required to slow telomere shortening and extend replicative lifespan of HSC during serial transplantation. Blood 102: 517-520.

Alter, B.P., Baerlocher, G.M., Savage, S.A., Chanock, S.J., Weksler, B.B., Willner, J.P., Peters, J.A., Giri, N., and Lansdorp, P.M. 2007. Very short telomere length by flow fluorescence in situ hybridization identifies patients with dyskeratosis congenita. Blood 110: 1439-1447.

Armanios, M., Chen, J.L., Chang, Y.P., Brodsky, R.A., Hawkins, A., Griffin, C.A., Eshleman, J.R., Cohen, A.R., Chakravarti, A., Hamosh, A., et al. 2005. Haploinsufficiency of telomerase reverse transcriptase leads to anticipation in autosomal dominant dyskeratosis congenita. Proc. Natl. Acad. Sci. 102: 15960-15964.

Armanios, M.Y., Chen, J.J., Cogan, J.D., Alder, J.K., Ingersoll, R.G., Markin, C., Lawson, W.E., Xie, M., Vulto, I., Phillips, J.A.R., et al. 2007. Telomerase mutations in families with idiopathic pulmonary fibrosis. N. Engl. J. Med. 356: 13171326.

Barnett, M.A., Buckle, V.J., Evans, E.P., Porter, A.C., Rout, D., Smith, A.G., and Brown, W.R. 1993. Telomere directed fragmentation of mammalian chromosomes. Nucleic Acids Res. 21: 27-36.

Baumann, P. and Cech, T.R. 2001. Pot1, the putative telomere end-binding protein in fission yeast and humans. Science 292: 1171-1175.

Blasco, M.A., Lee, H.W., Hande, M.P., Samper, E., Lansdorp, P.M., DePinho, R.A., and Greider, C.W. 1997. Telomere shortening and tumor formation by mouse cells lacking 
telomerase RNA. Cell 91: 25-34.

Byers, H.R., Maheshwary, S., Amodeo, D.M., and Dykstra, S.G. 2003. Role of cytoplasmic dynein in perinuclear aggregation of phagocytosed melanosomes and supranuclear melanin cap formation in human keratinocytes. J. Invest. Dermatol. 121: $813-820$.

Cerone, M.A., Ward, R.J., Londono-Vallejo, J.A., and Autexier, C. 2005. Telomerase RNA mutated in autosomal dyskeratosis congenita reconstitutes a weakly active telomerase enzyme defective in telomere elongation. Cell Cycle 4: 585589.

Cohen, S., Me, G., Lovrecz, G.O., Bache, N., Robinson, P.J., and Reddel, R.R. 2007. Protein composition of catalytically active human telomerase from immortal cells. Science 315: 1850-1853.

Cristofari, G. and Lingner, J. 2006. Telomere length homeostasis requires that telomerase levels are limiting. EMBO J. 25: 565-574.

Cui, R., Widlund, H.R., Feige, E., Lin, J.Y., Wilensky, D.L., Igras, V.E., D'Orazio, J., Fung, C.Y., Schanbacher, C.F., Granter, S.R., et al. 2007. Central role of p53 in the suntan response and pathologic hyperpigmentation. Cell 128: 853-864.

de Lange, T. 2005. Shelterin: The protein complex that shapes and safeguards human telomeres. Genes \& Dev. 19: 21002110.

Dokal, I. and Vulliamy, T. 2005. Telomerase deficiency and human disease. In Telomeres (eds. T. de Lange et al.), pp. 139-162. Cold Spring Harbor Laboratory Press, Cold Spring Harbor, NY.

Erdmann, N., Liu, Y., and Harrington, L. 2004. Distinct dosage requirements for the maintenance of long and short telomeres in mTert heterozygous mice. Proc. Natl. Acad. Sci. 101: 6080-6085

Gates, R.R. and Zimmermann, A.A. 1953. Comparison of skin color with melanin content. J. Invest. Dermatol. 21: 339348 .

Gavrieli, Y., Sherman, Y., and Ben-Sasson, S.A. 1992. Identification of programmed cell death in situ via specific labeling of nuclear DNA fragmentation. J. Cell Biol. 119: 493-501.

Gottschling, D.E. and Zakian, V.A. 1986. Telomere proteins: Specific recognition and protection of the natural termini of Oxytricha macronuclear DNA. Cell 47: 195-205.

Griffith, J.D., Comeau, L., Rosenfield, S., Stansel, R.M., Bianchi, A., Moss, H., and de Lange, T. 1999. Mammalian telomeres end in a large duplex loop. Cell 97: 503-514.

Hao, L.Y., Armanios, M., Strong, M.A., Karim, B., Feldser, D.M., Huso, D., and Greider, C.W. 2005. Short telomeres, even in the presence of telomerase, limit tissue renewal capacity. Cell 123: 1121-1131.

Hathcock, K.S., Hemann, M.T., Opperman, K.K., Strong, M.A., Greider, C.W., and Hodes, R.J. 2002. Haploinsufficiency of mTR results in defects in telomere elongation. Proc. Natl. Acad. Sci. 99: 3591-3596.

Heiss, N.S., Knight, S.W., Vulliamy, T.J., Klauck, S.M., Wiemann, S., Mason, P.J., Poustka, A., and Dokal, I. 1998. Xlinked dyskeratosis congenita is caused by mutations in a highly conserved gene with putative nucleolar functions. Nat. Genet. 19: 32-38.

Hockemeyer, D., Daniels, J.P., Takai, H., and de Lange, T. 2006. Recent expansion of the telomeric complex in rodents: Two distinct POT1 proteins protect mouse telomeres. Cell 126: 63-77.

Hockemeyer, D., Palm, W., Else, T., Daniels, J.P., Takai, K.K., Ye, J.Z., Keegan, C.E., de Lange, T., and Hammer, G.D. 2007. Telomere protection by mammalian POT1 requires interaction with TPP1. Nat. Struct. Mol. Biol. 14: 754-761.
Jacobs, J.J. and de Lange, T. 2004. Significant role for p16(INK4a) in p53-independent telomere-directed senescence. Curr. Biol. 14: 2302-2308.

Lazzerini Denchi, E. and de Lange, T. 2007. Protection of telomeres through independent control of ATM and ATR by TRF2 and POT1. Nature 448: 1068-1071.

Lee, H.W., Blasco, M.A., Gottlieb, G.J., Horner 2nd, J.W., Greider, C.W., and DePinho, R.A. 1998. Essential role of mouse telomerase in highly proliferative organs. Nature 392: 569574.

Lingner, J., Cooper, J.P., and Cech, T.R. 1995. Telomerase and DNA end replication: No longer a lagging strand problem? Science 269: 1533-1534.

Liu, Y., Snow, B.E., Hande, M.P., Yeung, D., Erdmann, N.J., Wakeham, A., Itie, A., Siderovski, D.P., Lansdorp, P.M., Robinson, M.O., et al. 2000. The telomerase reverse transcriptase is limiting and necessary for telomerase function in vivo. Curr. Biol. 10: 1459-1462.

Loayza, D. and de Lange, T. 2003. POT1 as a terminal transducer of TRF1 telomere length control. Nature 424: 10131018.

Makarov, V.L., Hirose, Y., and Langmore, J.P. 1997. Long G tails at both ends of human chromosomes suggest a $\mathrm{C}$ strand degradation mechanism for telomere shortening. Cell 88: 657-666.

Maringele, L. and Lydall, D. 2002. EXO1-dependent singlestranded DNA at telomeres activates subsets of DNA damage and spindle checkpoint pathways in budding yeast yku70s mutants. Genes \& Dev. 16: 1919-1933.

Marrone, A., Stevens, D., Vulliamy, T., Dokal, I., and Mason, P.J. 2004. Heterozygous telomerase RNA mutations found in dyskeratosis congenita and aplastic anemia reduce telomerase activity via haploinsufficiency. Blood 104: 3936-3942.

Marrone, A., Walne, A., Tamary, H., Masunari, Y., Kirwan, M., Beswick, R., Vulliamy, T., and Dokal, I. 2007. Telomerase reverse-transcriptase homozygous mutations in autosomal recessive dyskeratosis congenita and Hoyeraal-Hreidarsson syndrome. Blood 110: 4198-4205.

McChesney, P.A., Aisner, D.L., Frank, B.C., Wright, W.E., and Shay, J.W. 2000. Telomere dynamics in cells with introduced telomerase: A rapid assay for telomerase activity on telomeres. Mol. Cell Biol. Res. Commun. 3: 312-318.

Meier, U.T. 2006. How a single protein complex accommodates many different H/ACA RNAs. Trends Biochem. Sci. 31: 311-315

Mitchell, J.R., Wood, E., and Collins, K. 1999. A telomerase component is defective in the human disease dyskeratosis congenita. Nature 402: 551-555.

Mochizuki, Y., He, J., Kulkarni, S., Bessler, M., and Mason, P.J. 2004. Mouse dyskerin mutations affect accumulation of telomerase RNA and small nucleolar RNA, telomerase activity, and ribosomal RNA processing. Proc. Natl. Acad. Sci. 101: 10756-10761.

Nikaido, R., Haruyama, T., Watanabe, Y., Iwata, H., Iida, M., Sugimura, H., Yamada, N., and Ishikawa, F. 1999. Presence of telomeric G-strand tails in the telomerase catalytic subunit TERT knockout mice. Genes Cells 4: 563-572.

Palm, W. and de Lange, T. 2008. How shelterin protects mammalian telomeres. Annu. Rev. Genet. (in press).

Prowse, K.R. and Greider, C.W. 1995. Developmental and tissue-specific regulation of mouse telomerase and telomere length. Proc. Natl. Acad. Sci. 92: 4818-4822.

Rudolph, K.L., Chang, S., Lee, H.W., Blasco, M., Gottlieb, G.J., Greider, C., and DePinho, R.A. 1999. Longevity, stress response, and cancer in aging telomerase-deficient mice. Cell 96: $701-712$. 
Rudolph, K.L., Chang, S., Millard, M., Schreiber-Agus, N., and DePinho, R.A. 2000. Inhibition of experimental liver cirrhosis in mice by telomerase gene delivery. Science 287: 12531258.

Ruggero, D., Grisendi, S., Piazza, F., Rego, E., Mari, F., Rao, P.H., Cordon-Cardo, C., and Pandolfi, P.P. 2003. Dyskeratosis congenita and cancer in mice deficient in ribosomal RNA modification. Science 299: 259-262.

Sarin, K.Y., Cheung, P., Gilison, D., Lee, E., Tennen, R.I., Wang, E., Artandi, M.K., Oro, A.E., and Artandi, S.E. 2005. Conditional telomerase induction causes proliferation of hair follicle stem cells. Nature 436: 1048-1052.

Savage, S.A., Giri, N., Baerlocher, G.M., Orr, N., Lansdorp, P.M., and Alter, B.P. 2008. TINF2, a component of the shelterin telomere protection complex, is mutated in dyskeratosis congenita. Am. J. Hum. Genet. 82: 501-509.

Smogorzewska, A. and de Lange, T. 2002. Different telomere damage signaling pathways in human and mouse cells. EMBO J. 21: 4338-4348.

Stewart, S.A., Hahn, W.C., O'Connor, B.F., Banner, E.N., Lundberg, A.S., Modha, P., Mizuno, H., Brooks, M.W., Fleming, M., Zimonjic, D.B., et al. 2002. Telomerase contributes to tumorigenesis by a telomere length-independent mechanism. Proc. Natl. Acad. Sci. 99: 12606-12611.

van Steensel, B., Smogorzewska, A., and de Lange, T. 1998. TRF2 protects human telomeres from end-to-end fusions. Cell 92: 401-413.

Vaziri, H., Dragowska, W., Allsopp, R.C., Thomas, T.E., Harley, C.B., and Lansdorp, P.M. 1994. Evidence for a mitotic clock in human hematopoietic stem cells: Loss of telomeric DNA with age. Proc. Natl. Acad. Sci. 91: 9857-9860.

Vulliamy, T., Marrone, A., Goldman, F., Dearlove, A., Bessler, M., Mason, P.J., and Dokal, I. 2001. The RNA component of telomerase is mutated in autosomal dominant dyskeratosis congenita. Nature 413: 432-435.

Vulliamy, T., Marrone, A., Szydlo, R., Walne, A., Mason, P.J., and Dokal, I. 2004. Disease anticipation is associated with progressive telomere shortening in families with dyskeratosis congenita due to mutations in TERC. Nat. Genet. 36: 447-449.

Walne, A.J., Vulliamy, T., Marrone, A., Beswick, R., Kirwan, M., Masunari, Y., Al-Qurashi, F.H., Aljurf, M., and Dokal, I. 2007. Genetic heterogeneity in autosomal recessive dyskeratosis congenita with one subtype due to mutations in the telomerase-associated protein NOP10. Hum. Mol. Genet. 16: $1619-1629$.

Westin, E.R., Chavez, E., Lee, K.M., Gourronc, F.A., Riley, S., Lansdorp, P.M., Goldman, F.D., and Klingelhutz, A.J. 2007. Telomere restoration and extension of proliferative lifespan in dyskeratosis congenita fibroblasts. Aging Cell 6: 383-394.

Wong, J.M. and Collins, K. 2006. Telomerase RNA level limits telomere maintenance in X-linked dyskeratosis congenita. Genes \& Dev. 20: 2848-2858.

Wong, J.M., Kyasa, M.J., Hutchins, L., and Collins, K. 2004. Telomerase RNA deficiency in peripheral blood mononuclear cells in X-linked dyskeratosis congenita. Hum. Genet. 115: 448-455.

Wu, L., Multani, A.S., He, H., Cosme-Blanco, W., Deng, Y., Deng, J.M., Bachilo, O., Pathak, S., Tahara, H., Bailey, S.M., et al. 2006. Potl deficiency initiates DNA damage checkpoint activation and aberrant homologous recombination at telomeres. Cell 126: 49-62.

Yaghmai, R., Kimyai-Asadi, A., Rostamiani, K., Heiss, N.S., Poustka, A., Eyaid, W., Bodurtha, J., Nousari, H.C., Hamosh, A., and Metzenberg, A. 2000. Overlap of dyskeratosis congenita with the Hoyeraal-Hreidarsson syndrome. I. Pediatr.
136: 390-393.

Yamaguchi, H., Baerlocher, G.M., Lansdorp, P.M., Chanock, S.J., Nunez, O., Sloand, E., and Young, N.S. 2003. Mutations of the human telomerase RNA gene (TERC) in aplastic anemia and myelodysplastic syndrome. Blood 102: 916-918.

Yamaguchi, H., Calado, R.T., Ly, H., Kajigaya, S., Baerlocher, G.M., Chanock, S.J., Lansdorp, P.M., and Young, N.S. 2005. Mutations in TERT, the gene for telomerase reverse transcriptase, in aplastic anemia. N. Engl. J. Med. 352: 14131424.

Zhu, J., Wang, H., Bishop, J.M., and Blackburn, E.H. 1999. Telomerase extends the lifespan of virus-transformed human cells without net telomere lengthening. Proc. Natl. Acad. Sci. 96: 3723-3728. 


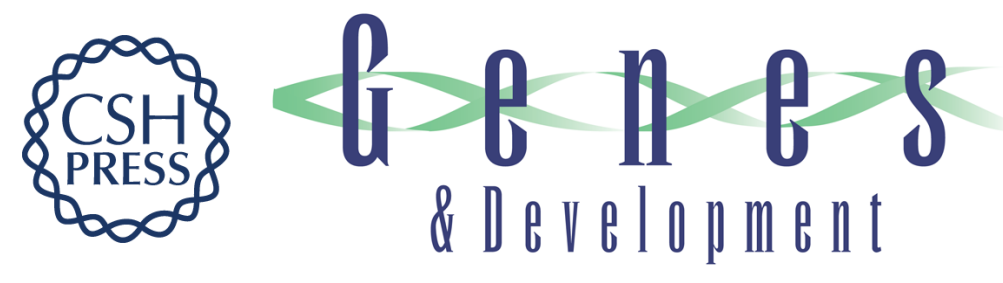

\section{Engineered telomere degradation models dyskeratosis congenita}

Dirk Hockemeyer, Wilhelm Palm, Richard C. Wang, et al.

Genes Dev. 2008, 22: originally published online June 11, 2008

Access the most recent version at doi:10.1101/gad.1679208

\footnotetext{
Supplemental http://genesdev.cshlp.org/content/suppl/2008/06/11/gad.1679208.DC1

Material

Related Content POT of gold: modeling dyskeratosis congenita in the mouse

Chantal Autexier

Genes Dev. July , 2008 22: 1731-1736

References This article cites 59 articles, 23 of which can be accessed free at: http://genesdev.cshlp.org/content/22/13/1773.full.html\#ref-list-1

Articles cited in:

http://genesdev.cshlp.org/content/22/13/1773.full.html\#related-urls

License

Email Alerting

Service

Receive free email alerts when new articles cite this article - sign up in the box at the top right corner of the article or click here.
}

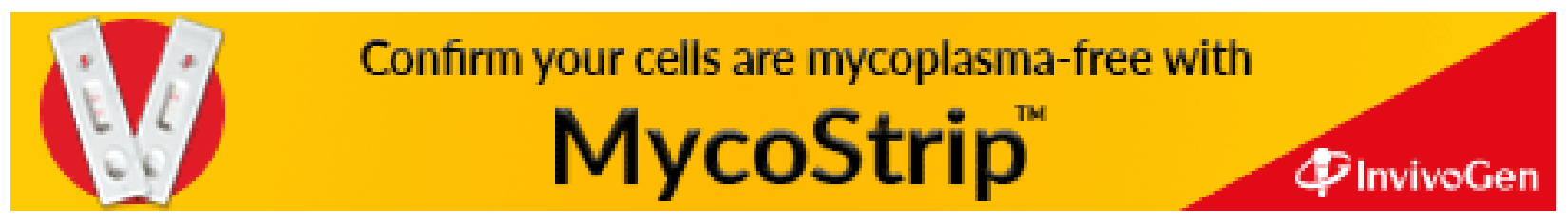

